\title{
IIICTR ILCEA
}

Revue de l'Institut des langues et cultures

d'Europe, Amérique, Afrique, Asie et Australie

$40 \mid 2020$

English for Specific Purposes (ESP) and the Underlying Dynamics of Power, Empowerment and Disempowerment

\section{Power and Norm-Setting in LSP: Anglicisms in the Language of Fashion Influencers}

Le pouvoir de la définition des normes en langues de spécialité: les anglicismes dans le langage des « influenceurs" de la mode

\section{Miguel Ángel Campos-Pardillos and Isabel Balteiro}

\section{OpenEdition}

\section{Journals}

Electronic version

URL: http://journals.openedition.org/ilcea/10499

DOI: 10.4000/ilcea.10499

ISSN: 2101-0609

\section{Publisher}

UGA Éditions/Université Grenoble Alpes

\section{Printed version}

ISBN: 978-2-37747-204-8

ISSN: 1639-6073

\section{Electronic reference}

Miguel Ángel Campos-Pardillos and Isabel Balteiro, « Power and Norm-Setting in LSP: Anglicisms in the Language of Fashion Influencers », ILCEA [Online], 40 | 2020, Online since 04 June 2020, connection on 03 September 2020. URL : http://journals.openedition.org/ilcea/10499 ; DOI : https:// doi.org/10.4000/ilcea.10499

This text was automatically generated on 3 September 2020

(C) ILCEA 


\title{
Power and Norm-Setting in LSP: Anglicisms in the Language of Fashion Influencers
}

\author{
Le pouvoir de la définition des normes en langues de spécialité : les anglicismes \\ dans le langage des « influenceurs» de la mode
}

Miguel Ángel Campos-Pardillos and Isabel Balteiro

\section{Introduction}

1 Languages for Specific Purposes and their linguistic genres and features have already been largely discussed in the literature. However, the developments and changes in present-day societies and the resulting impact on new professions and language at all levels (i.e. specialized, professional or general) are now a dynamic area of emerging research.

2 Accordingly, the present paper addresses a new and, to our knowledge, undertheorized line of enquiry, i.e. the language of fashion "influencers" in the general context of professional languages. More precisely, the paper focuses on the power exerted by these new "professionals" as regards norm-setting or the normativization of the specialized or specific lexis of their field (fashion, in this case). After a brief overview of the general context and background of LSP, we then deal with the language of fashion, which we characterize as a power that may be moveable or dynamic. In the following section, we focus on the increasing power of and battle surrounding fashion Anglicisms in social media, with particular focus on the case of "influencers" and their power over (and against) established language tendencies and norms. Despite the inevitable limitations related to the innovative and emerging character of this research, we hope to contribute towards opening up similar fields of discussion and research within the area of LSP, and specially, the language of fashion. 


\section{Power and languages for specific purposes}

3 The organization of society into activities and professions has led to the advent of what has been called "languages for specific purposes", an umbrella term for academic, professional or occupational languages. Professional languages, the object of this paper, may be defined as the language of a particular profession, common to all its practitioners, and a prerequisite for all aspiring members. Such language requires some implicit or explicit degree of codification, what Giddens (1984) calls "discursive consciousness" (including lexical or terminological consciousness), a process which is closely related to power issues.

4 The issue of power in professional or specialized languages usually focuses on the analysis of language as an instrument, i.e. language as used to exert power over people. Whether this occurs within the same language (endolingual contexts) or across languages (cross-cultural or exolingual contexts), in both cases, language becomes a symbol of group membership: those who master a given code belong to the community, the others do not.

5 In endo- and exolingual contexts, the professions are "specialized communities aiming to dominate, police and protect their particular area of expertise" (Orts \& Breeze, 2017: 10). Even within the same society, specialized language may be used to show knowledge and mastery (and therefore, superiority based on such mastery) of a given area within a specific community. As such, this specialized language may also serve to persuade outsiders, including members of other communities, about the importance of a given profession, the importance of products (advertising) and procedures (medicine), or to attract attention (fashion, advertising).

6 At an international level, English is often seen as an instrument of colonization, employed to impose Western-centred ideologies, practices and culture. The exercise of a profession is thus also conditioned by such use of language, creating a situation of dominance and disempowerment rarely addressed in ESP studies which has led certain scholars to point out that "ESP is too often untroubled by questions of power" (Belcher, 2006).

7 This power structure is, of course, by no means a monolithic and/or eternal one, and may be subverted in many ways. On the global scene, we witness a paradoxical imbalance of power, since more people speak English as a second or foreign language than as a native language (see, for instance, Crystal, 2003: 69; or Graddol, 2006:110). Even though the power of English as a lingua franca in most professional and scientific communities continues to give native professionals an unfair edge when accessing such communities, this superiority is being steadily eroded by non-native speakers of English who may get to "reshape English for their own purposes" (Paltridge \& Starfield, 2011: 117). One example of such (mis)appropriation of English, for instance, concerns the introduction of false Anglicisms in standard professional languages (see Balteiro, 2011a, 2011b, 2011c).

8 Within the same language context, professional codes controlled by specific groups may come "under attack" from other groups existing on the periphery of such communities who seek to have their views and terminology prevail, as we shall see in the following discussion. Furthermore, "outliers" or even non-members of specific communities have been able to "democratize" the grammar and lexis of specialized 
languages to some extent, as, for example, in the case of legal-notably with the wellknown Plain English campaign-or pharmaceutical languages.

While we agree that these two manifestations of power, i.e. the continuing advantage for native speakers, on the one hand, and Plain English, on the other, are certainly real, there is the danger that perceptions of the specialized language may be obscured by treating it as a pre-existing element, something that "is already there", and wielded for control or colonization. We might, however, take a step back in the process, and wonder how specialized language is developed, because it is here that issues of power are dramatically present: (not so) metaphorically speaking, language is a weapon, and the configuration of the weapon is tailored by and for those who design it, ensuring they always have the upper hand by imposing their own linguistic varieties. In the present paper and its focus on non-hierarchical LSP communities, we posit that one of the observable signs of power is setting the standard, i.e. deciding what is correct or not in a given practice and, more importantly, deciding who it is that decides what is correct.

The way such power over the norm is structured is largely dependent on the organization of user communities (more or less specialized/professional, allowing for a certain degree of conflation), and to what extent these communities are defined and/or structured. In this respect, gaining membership to a professional community is usually viewed as an organized and clearly regulated process, with covert "gatekeeping" functions. Thus, becoming a physician requires fulfilling a number of prerequisites, starting with university admission, completing a required number of modules, followed by a period of postgraduate specialization (often including an admission examination), Furthermore, even if no further requirement as, for example, a competitive examination for a position in the public sector, is needed, it is often deemed essential, in some parts of the world, to also be a member of a medical association. In the case of lawyers, the academic process is largely the same, followed by postgraduate courses, compulsory training, and eventually admission to the Bar Council. All these stages are "controlled", structured or regulated by professionals or academics or academics-cumprofessionals and heavily regulated by governmental rules. In these structured professions, membership includes knowledge of the profession's peculiar use of language. Such control may be exercised in two ways: first, explicitly, by members of the profession, either through established bodies regulating professional practice (e.g. medical associations or bar councils, membership of which is obligatory to practice in certain countries), or through academic publications (journals, handbooks, etc.) in which case control is exercised by editors and reviewers); and second, implicitly and in a less formally structured way, by users or professionals themselves in that acceptability is correlated to frequency of usage by members of a given profession or amateurs with a high degree of specialization (see examples in Campoy-Cubillo et al., 2010; and for the debate on corpus usage, see Flowerdew, 2005).

11 In the case of certain professions, a third category may be added to the two evoked above, namely, that of professionals who are not necessarily domain specialists but nevertheless exercise power over the language used as, for example, in the case of law, where politicians morph into legislators. This applies especially when the wording of a legal instrument predetermines the definitions of terms to be used later in professional practice, as illustrated by an act defining, for instance, the meaning of "timesharing" in the field of property management, or "customer" in cross-border sales of goods and 
services. This may be considered as an additional category since, even though legal drafters and legislators do have a legal background and/or training, they are not members of the legal professions as such.

In most regulated professional discourses, the pre-established norm is determined at micro- and macrostructural levels for the sake of standardization. At the lexical level there are, for instance, pre-established terminology lists, statutory definitions, etc. At the macrostructural level, text types are also previously defined and quasi formulaic: medical certificates or consent forms, for example, are pre-existent and follow specific moves which are compulsory (both as a result of established practice or normative requirements in some jurisdictions). The microstructural level, however, can be determined by the macrostructural one: genres, for instance, may predetermine the use of specific words or phraseological structures as is the case for the phrases "He proved to me on the basis of satisfactory evidence to be the person whose name is subscribed to the within instrument" which is to be found in notary certificates. ${ }^{1}$

The benefits of such standardization for professional practice are manifold. In addition to the (often criticized) fact that adoption of correct usage conditions the fact of belonging to a given group and serves as a "badge of membership", it also facilitates communication and provides a degree of certainty in case of dispute. Lemens and Adams (2015), when arguing in favor of standard terms and phrases in contracts and against language simplification, mention that established case law offers a safe interpretation of traditional terms and phrases (no matter how old-fashioned), while using alternative, simpler vocabulary becomes "untrodden ground" with the risk of unexpected interpretations and court rulings in case of disagreement. On another note, such a high degree of predictability at both the macro- and microstructural levels is also extremely useful for those who seek to acquire a given professional "language" or enter the given community, either as an L1 (new members of the community) or as an L2 (foreign learners entering the profession in a foreign country, communicating at an international level, or translators). Language trainers and translators make extensive use of specialized dictionaries and LSP handbooks which would be much harder to draft-and probably not be accepted by professionals-, were it not for this predictability. These language practices, however, apply to the already mentioned "hierarchical" or "regulated" professions, access to and exercise of which are subject to possession of specific professional qualifications and to maintaining specific conditions, as exemplified by medicine and law $^{2}$ where the power structure is clear.

In contrast to these, there exist other "non-hierarchical" or even "non-regulated" professions or areas of LSP, where empowerment is more "democratic" in that there are no formal gatekeepers to the profession in the form of admission requirements or other pre-established qualifications. The situation may be viewed as a gradation ranging from the "regulated", "well-kept professions", on one end of the spectrum, and the less formal or even non-regulated professions, on the other end. Examples of this end of the spectrum are fashion design or sports journalism, two "disciplines" marked by the paradox that though graduate and postgraduate programmes in sports journalism and fashion design do exist, the fact that they are not "regulated professions" allows persons without any formal training in sports journalism to become journalists, as clearly evidenced by the number of former football players and coaches with basic or no journalism qualifications who become "professional" match commentators, or "celebrities" who become fashion designers. 
15 In the context of this discussion on the dynamics of ESP as a force of power and empowerment, it is worth highlighting that when such "self-made" people with no formal qualifications integrate the profession, they also accede to the "power" to influence existing standards through proposing and imposing their own terms: in football journalism, for example, the term tiki-taka (a style of play characterized by maintaining possession and frequent passing) was created by football coaches and has subsequently been embraced by journalists worldwide. ${ }^{3}$

The fact that certain professions require no academic qualifications plays an important role in terms of register, i.e. the use of informal language. This helps explain the characteristic "informality" of certain professional languages, as for instance, the "popular" nature of the language of finance-marked by colloquialisms and metaphors, such as "poison pill" or "bear hug" (see Bielenia-Grajewska, 2009; or Resche, 2015)-, as compared to the language of theoretical economics, as pointed out by Mateo (2014). One obvious reason for this difference in register is arguably that, while economics requires specific educational qualifications, for stock exchange brokers a university degree could be a bonus, but is not an admission requirement. The absence of academic prerequisites may also operate at the higher level of the mindset, in that the ethos of academe has the effect of "disciplining" users so that they accept authority, preexisting codes, and the need for approval of new elements, whereas members who have not been "subject to the rules" do not feel the need to conform to what is expected, or rather, will learn from parallel, more "popular" unorthodox models.

These non-regulated professions-and, to some extent, also certain professions in between the two extremes, such as international trade, where academic qualifications do exist, but are not a sine qua non requirement and so do not constitute a gatekeeping barrier-establish no clearly defined borders between lay and professional users. Unlike in law and medicine, where one is either a lawyer or a physician and therefore, authorized to practice, or one is not and hence permission to practice is refused, in other professions we find a gradation. Such gradation may be visualized as a series of concentric circles progressively approaching the "core", which in turn, may also be a fuzzy one, or even respond to a different set of definitions, thus leaving room for "selfmade persons" or "on-the-job training" as potential possibilities for such an approach.

One of the main differences between less-experienced, non-regulated or "peripheral" users is that their training has not been a formal one, and therefore the likelihood of a stabilized form of language is lower, as opposed to doctors and lawyers, for instance, who are trained by other lawyers and doctors and thus perpetuate the professional order much in the same line as the Bourdieusian social order. In this respect, the less formal, more accessible discourse of the "peripheral user" represents a source of power by making it being easier to approach the most important stakeholders involved, i.e. the lay addressee. In the case of sports journalists, for example, those aiming to approach the circles of power (e.g. former players or coaches who comment football matches for the sports channel ESPN) tend either to develop their own terms, metaphors and expressions, or follow the model of those commentators they like best. The explanation lies in the fact that they have been exposed to a variety of influences, most of them informal, and have not been prevented, during their "training", from using non-pre-established lexicon. If anything, they have been hired precisely because the freshness of their approach to "professional" language makes them attractive to media planners. Likewise, as regards fashion, the ability to innovate and use language 
closer to lay persons instead of adhering to pre-existent terminology makes the "peripheral user" of a specialized language, i.e. the blogger or the influencer, attractive for major brands.

\section{The language of fashion: the power of "influencers"}

19 The fashion industry serves to illustrate the changing dynamics of power and empowerment, the differences between the regulated and non-regulated professions and the resulting hierarchical consequences. Unlike other more classic professional areas, it is easy to identify the "members" of this users' community. As discussed earlier, the concept of "membership" acquires a different meaning in these contexts since, if it is clear that fashion designers, brands, etc., are "core" users, there is nevertheless a wide constellation of more or less "empowered" users who influence content and, what is more pertinent in the context of this article, even form.

In the area of fashion, the lack of control over language output is enhanced by macrostructural characteristics: unlike the codified genres of other traditional professional languages, genres here are widely diverse in nature and, most importantly, without any filter for output to reach audiences. This is specially the case with regard to the Internet: if in the past, fashion magazines, fashion exhibitions and large-scale manufacturers were the main source of information and normative prescription, at present the fundamental requirement is the ability to attract attention on social media. The channels may be blogs, vlogs, but also Instagram, Facebook and Twitter. The persons behind such channels can vary from journalists, former or practicing models, persons with some formal or professional training, to simply fashion followers. However, what they all share in common is that they are "aspiring" members, since their purpose is not only to disseminate their ideas but, in so doing, ensure that their status within the world of fashion-in terms of number of followers and recognition by the media and the brands themselves-is constantly on the increase, so as to eventually become a means of livelihood. This is greatly facilitated by the fact that, unlike the "formal admission" requirements existing in other professional areas, these persons have the ability to move towards the "core" of the profession by agreeing to sponsor products and/or become part of advertising campaigns, for instance.

One of the most widely known examples of such social-media based commercial activity is the so-called "influencer", "the name given to the broad church of people who create and monetize original content on social media" (The Guardian, 23 January 2020). They are people who usually come from outside the industry: celebrities such as actors, singers, sportswomen and sportsmen, but also self-made fashion promoters who have never been celebrities at all. These persons enter the "power structure" of the fashion industry by supporting new brands, providing products with a spontaneous, fresh image and, most importantly, ensuring the presence of brands on social media through monetising their "followers". By acquiring this power, and thanks to the fact that they have effectively entered the value chain in the fashion industry, they not only become de facto members of the profession but also acquire power over the language used in this specialized context.

One of the earliest definitions of an influencer and the nature of the power they may wield comes from Freberg et al. who coined the acronym SMI ("social media influencer") to define a "new type of independent third party endorser who shapes 
audience attitudes through blogs, tweets, YouTube and the use of other social media" (2011: 90) - a definition which could be updated by evoking the emergence of Instagram as the major communication channel today in this context.

What is more interesting for our purposes here is that, in the case of the fashion industry, the concept of "third party", which here refers to a person who is, in fact, neither the seller or the end user of a product, takes on new relevance. The whole purpose of influencers, whose main function is basically to disseminate their personal ideas and preferences about fashion amongst their myriad "followers", is to build themselves up as prominent agents so as to be able to monetize the power such a position bestows. Simply motivated by a desire to use social media as a means of earning their livelihood, influencers rarely have any academic or formal training in fashion design, marketing or retailing; equally, they may have (or have had) other means of livelihood (modelling, singing, acting, or simply a large fortune making it unnecessary to exercise any trade at all). This phenomenon is closely connected to the Internet, since in the past any similar type of influence could only operate either in informal settings (the "unacquainted influencer" encountered while shopping, as described in McGrath \& Otnes, 1995), or through the classic filters of advertising or traditional media, such as, for example, a celebrity using or sponsoring a product.

From the point of view of language use and language power, along with the characteristic lack of formal training, another important trait of influencer communication is the absence of any overseeing controlling filters: influencers either post their views directly, or through a PR service, which means that there is little control regarding form and content by standardized media. This differs greatly, for instance, from the language of fashion magazines where, as is the case with the print press in general, either there is a style sheet to provide language use guidelines or an editor to revise texts before publication. The underlying signification of such freedom of control is that terminological choices are not subject to any imposed standardization. As such, influencers may, to some extent, be considered the extreme example of the "democratization" of communication, i.e. the power of a given person to reach and influence a massive number of users without any mediation.

The status of an "influencer" is not a binary one in that one does not "become" an influencer only once specific criteria are met. Understandably, status can be viewed as a question of perception, as described by Polsby over half a century ago, according to which people sometimes perceived as leaders are "those persons who have the reputation for being influential" (1959: 796), a reputation which may or may not be justified by behaviour. The absence of clear defining criteria becomes egregious when we consider that one may become an influencer at a small scale, giving rise to the category of "micro"- and "macro-influencers", a trend which appears to be gaining in momentum in view of the recent rise of "nano-influencers" (Mahesvari, 2018). These are persons with comparatively few followers (e.g. 1,000) and who will, in exchange for free products or a small fee, promote any message suggested by companies, as defined by Mediakix, a US influencer marketing agency:

A nano-influencer is defined as an Instagram influencer with between 1,000 and 10,000 followers. Nano-influencers' audiences are small, niche, and highly engaged -the smallest following of all tiers of influencers (with tiers defined based on the total number of Instagram followers). Compared to everyday Instagram users, nano-influencers might not seem distinct. Nano-influencers are users who post sponsored Instagram posts by partnering with brands. 
26

though "influencing" represented a global worth of £8bn in 2019 (The Sunday Times, 8 September 2019), it is not a regulated sector of activity. There is no specifically set number of followers which defines someone as an influencer: while we all agree that having 145 million followers certainly does entitle Kim Kardashian, US media personality, businesswoman, socialite, model and actress, to be legitimately considered an influencer, there are, nevertheless, those with "only" one million or one hundred thousand followers, and others who were not famous before they started out. Evidence of this lack of clarity was highlighted by a recent ruling by the British Advertising Standards Authority (ASA, 2019) on whether a person with 32,000 followers could be considered a celebrity. Contrary to corporate claims, the ASA ruled that "over 30,000 followers indicated that [the person] had the attention of a significant number of people" and therefore "was a celebrity for the purposes of the CAP [Code of Advertising Practice]". While this certainly may not be considered a definite answer, it does illustrate the relative nature of "influencer" status and category, and most importantly, the upwardly mobile nature of influencers characterised by the constant resolve to increase their number of followers and thus their sphere and power of influence.

In addition to their "influencing" power in terms of pure sponsorship-a product can sell out instantaneously if sponsored on an Instagram account,$-{ }^{4}$ influencers on social media are also in a position to promote aspects of language use. Although such language, admittedly, targets the general public, it may, through the influence gained over an ever-widening general public, raise influencers to a position where their audiences may also include domain specialists. One such example is the case of Dulceida, a Spanish influencer, who describes herself in her bilingual website as "Another amateur fashion girl", but boasts of having received the "Best Style Fashion Blog" award in Berlin Fashion Week, ${ }^{5}$ which puts her side-to-side with professionals. In other words, though influencers basically address themselves to the general public, fashion brands and designers come to tacitly recognize their power by making them part of their own advertising strategy and disseminating or even "imposing", through frequency of use, their language, lexical or terminological preferences.

\section{Fashion Anglicisms in social media: the lexical battle for power}

In this section, we concentrate on the "power battle" between prescriptive and descriptive terminological approaches, in order to study usage in the language of fashion by contrasting the efforts deployed to counter unorthodox innovations by prescriptivists and academics, and the informal lexicological preferences flaunted by influencers.

For our analysis, we have chosen to focus on Anglicisms in Spanish and the difference between what prescriptivists recommend, on the one hand, and actual usage by influencers or practitioners possessing the power of influencing further usage, on the other. In most cases, proposals providing "native" solutions to unadapted borrowings (essentially Anglicisms, in this context) are, not unsurprisingly, rejected by those who set the trends in usage.

The opinion on borrowings has largely changed over the past years. Linguists are progressively viewing them as a natural occurrence and not as an undesirable influence 
(see Balteiro, 2011a, on the prescriptivist/descriptivist debate) and gone are the times when linguists would use terms such as "invasion" (Pratt, 1997) in this context. At present, Anglicisms are described as an existing phenomenon, and the function of the linguist is not to prescribe, but simply to observe, analyze and describe the reasons for their usage. Today, it is only conservative academics who continue to promote patriotic linguistic integrity and complain about what they consider the "excessive" presence of Anglicisms, as we shall see below. In this context, our research over the last years has led us to study the abundance of unadapted Anglicisms-and even false Anglicisms (Balteiro \& Campos, 2012)-prevalent in the language and discourse of fashion, not with a view to proposing alternatives (which may simply not be there), but to focusing on the reasons for such usage through analysis of the language of magazines, bloggers and fashion designers.

31 As will be seen, the adoption or refusal of Anglicisms in this context is closely connected to the dynamics of power relations: if it is quite true that prescriptivists or users close to the "power circles" (e.g. brands, fashion show organizers, etc.) are in a position to decide whether such Anglicisms are accepted or not, especially in situations where both the practice and the language of a profession are regulated, as discussed above, it is also the case that those very Anglicisms which were initially rejected may eventually come to be accepted if supported by "aspiring" users who have reached a certain degree of power.

In order to view the present situation in this respect in Spanish, we compare usage on social media with the "native" solutions proposed by normative authorities and academics. In the case of the language of fashion in Spanish, the normative framework is provided by the Glosario de la Moda published by the Fundación del Español Urgente (Fundéu, 2015), which represents a conscious ongoing endeavor to prevent the use of what its adherents term "foreignisms" or extranjerismos (not "borrowings"). It last surfaced on the occasion of the Mercedes-Benz Fashion Week in Madrid in 2018, when it published lists of words recommending Spanish equivalents as a substitute for English borrowings, as presented below: 
Figure 1. - Fundéu recommendations for the avoidance of Anglicisms (2015).

\begin{tabular}{|c|c|c|}
\hline $\begin{array}{l}\text { backstage: bambalinas, } \\
\text { bastidores } \\
\text { casual: (estilo) informal } \\
\text { catwalk: pasarela } \\
\text { celebrities: famosos } \\
\text { clutch: bolso de mano, bolso de } \\
\text { fiesta, cartera } \\
\text { coolhunter: cazatendencias o } \\
\text { buscatendencias } \\
\text { denim: tejido vaquero, mezclilla } \\
\text { dress code: etiqueta, código de } \\
\text { vestimenta, reglas de vestimenta } \\
\text { fashion o trendy: de última } \\
\text { moda, de moda, lo último, } \\
\text { tendencia } \\
\text { fitting: prueba de vestuario } \\
\text { front row: primera fila } \\
\text { glitter: brillante }\end{array}$ & $\begin{array}{l}\text { it-girl: chica de moda, chica icono } \\
\text { jumpsuit: mono } \\
\text { look: imagen, estilo, aire } \\
\text { lookazo: modelazo, estilazo, imagen } \\
\text { espectacular o buen aspecto } \\
\text { lookbook: catálogo, porfolio o } \\
\text { libreta de tendencias } \\
\text { make up: maquillaje } \\
\text { monochrome: monocromático, } \\
\text { monocromo, monocolor } \\
\text { monogram: monograma } \\
\text { mule: babuchas, sandalias tipo } \\
\text { babucha } \\
\text { must o must have: (prendas, } \\
\text { accesorios...) imprescindibles o } \\
\text { infaltables }\end{array}$ & $\begin{array}{l}\text { new face: (para modelos) } \\
\text { cara nueva } \\
\text { outfit: conjunto } \\
\text { oversize: holgado } \\
\text { paillete: lentejuela } \\
\text { print: estampado } \\
\text { shooting: sesión fotográfica } \\
\text { shopping: ir de compras } \\
\text { showroom: } \\
\text { exposición } \\
\text { sneakers: } \\
\text { deportivas } \\
\text { sport wear: ropa deportiva } \\
\text { stretch: elástico } \\
\text { top model: supermodelo } \\
\text { tricot: punto }\end{array}$ \\
\hline
\end{tabular}

Source: <www.compartemimoda.es/2016/01/diccionario-fashionista.html>. underlying dynamics of lexical power control here, all the more so as the addressees are "plain users" who may come to occupy positions of relative power. While the campaign led by Fundéu, which publishes its glossary "on the occasion of a fashion show", is not aggressive, other media which report on the appearance of the glossary are more so, as for example, Heraldo de Aragón uses the heading “iAtención, 'bloggers' de moda! Las palabras que usáis también existen en español" ["Watch out, fashion bloggers! There are also words in Spanish for the words you use"] (¡Atención, 'bloggers' de moda!, 2018). For the modern linguist, such "do's and don'ts" established by prescriptivists seeking to expunge what they deem incorrect, are greatly reminiscent of, and as valuable as, the Appendix Probi drafted in late Roman times, a list of "mistakes" not to be made in Latin, but which have now become an invaluable source of information about the real state of the language at the time (Quirk, 2005). In a similar vein, in the case of our study, when prescriptivists propose "bambalinas/bastidores", " informal", "tejido vaquero/mezclilla" or "imagen" instead of backstage, casual, denim or look, the implicit information as regards usage in social media is that it is the contrary trend that is in actual use.

In addition to the glossaries published by professionals, there is a wide array of "unofficial" ones which usually come from the peripheral user community, and are included as part of topic-based websites (usually blogs). The references we use for our study are the Diccionario Fashionista (2016, henceforth ComparteModa) and the Diccionario de Moda (2018; henceforth EnFemenino). 
two glossaries have a purpose clearly stated at the outset. ComparteModa includes fashionista in the title, an "undesirable Anglicism" for others (if Fundéu, for example, does not accept fashion, its derivates will also be disregarded), and EnFemenino, which describes itself as a Diccionario moda/español-español/moda, considers the language of fashion as a language as per se, at the same level as "French" or "English". Anglicisms are not only admitted, but considered "the jargon in the industry", and described as a prerequisite to becoming an expert in the trade:

Esta temporada las trendsetters han dictado sentencia: se llevan los prints tye dye, combinados con unos buenos tacones peep toe, con una blazer y un clutch a juego. ¡El paraíso de todas las fashionistas!

Si tras leer esta frase te has quedado igual que si hubieras consultado un manual de chino mandarín, tenemos la solución para ti. Últimamente hemos adoptado tantos anglicismos, que comprender una revista de moda puede convertirse en una misión imposible, principalmente para las lectoras de a pie, que no tienen por qué conocer al dedillo la jerga del sector.

Por eso, la redacción de enfemenino ha preparado para ti un completo diccionario de moda que recoge el vocabulario necesario para ser una auténtica experta en materia e impresionar a todo el mundo con tu dominio de los términos más actuales. ${ }^{6}$

[This season, trendsetters have issued their judgment: tie dye prints are in, combined with good peep-toe heels, with a blazer and a clutch to match! The fashionista paradise!

If, after reading this sentence, you have understood as much as if it was a Chinese language handbook, we have the answer for you. Lately we have adopted so many Anglicisms that understanding a fashion magazine may become mission impossible, mainly for the everyday reader, who may not know the industry jargon to the last detail.

This is why the enfemenino writers have prepared a complete fashion dictionary for you, which contains all the vocabulary you need to be a real expert in the matter and impress everybody by mastering all the latest terms. $]^{7}$

The characteristic trait of such glossaries with regard to borrowings is that, unlike their prescriptivist counterparts, they seldom, if ever, recommend a "native" alternative. If necessary, they simply describe the term in context and/or provide usage examples, as illustrated by the entries below for fashionista and trendy in EnFemenino and boyfriend in Compartemoda: 
Figure 2. - Definitions from compartemimoda (2016).

\begin{tabular}{|c|c|}
\hline Fashionista & $\begin{array}{l}\text { Un fashionista es una persona que siente devoción por la moda, principalmente por las } \\
\text { prendas únicas o de alta costura. Sin embargo, es importante no confundir a este tipo de } \\
\text { personas con las que siguen de manera compulsiva las tendencias que aparecen cada nueva } \\
\text { temporada. Una verdadera fashionista es fiel a su estilo, sabe lo que le queda bien y lo que } \\
\text { no, y no se deja influenciar por tendencias pasajeras. } \\
\text { [A fashionista is a person in love with fashion, mainly with unique garments or haute } \\
\text { couture. However, it is important not to confuse these people with those who } \\
\text { compulsively follow the trends appearing every new season. A real fashionista is true } \\
\text { to her style, knows what looks good on her and what doesn't, and does not let herself } \\
\text { be influenced by short-lived trends.] }\end{array}$ \\
\hline Trendy & $\begin{array}{l}\text { La palabra Trendy engloba "todo lo que está de moda". Por eso, lo que una temporada es } \\
\text { tendencia y se considera trendy, puede estar desfasado la temporada siguiente. Este término, } \\
\text { además de aplicarse al mundo de la moda también puede usarse en muchos otros ámbitos, } \\
\text { como la música, el arte o la decoración. } \\
\text { [The word "trendy" includes "everything that is 'in"'. Therefore, what is considered } \\
\text { trendy this season may be out of fashion next season. This term applies to the world } \\
\text { of fashion, but may also be used in many other spheres, such as music, arts or } \\
\text { decoration.] }\end{array}$ \\
\hline Boyfriend & $\begin{array}{l}\text { Adaptación de la moda masculina a la moda femenina, es decir prendas holgadas y de aspecto } \\
\text { masculino que parece que las hayas cogido del armario de tu chico. Son ya archifamosos los } \\
\text { boyfriends jeans, boyfriends cardigans o boyfriends jumpers (jerseys). } \\
\text { [Adaptation of masculine fashion to feminine fashion, i.e. loose, masculine-looking } \\
\text { garments which look as if they've been grabbed from your boyfriend's wardrobe. } \\
\text { Some ultra-famous examples are boyfriends' jeans, boyfriends' cardigans or } \\
\text { boyfriends' jumpers.] }\end{array}$ \\
\hline
\end{tabular}

Source: <www.compartemimoda.es/2016/01/diccionario-fashionista.html>.

37 In order to illustrate the conflicting trends between prescriptivism and descriptivism, embodied by the academics, on the one hand, and the "peripheral users-cumlexicographers", on the other, and the ensuing difference in approaches to terminology, we compare the different proposals related to the use in specialized Spanish of three commonly used Anglicisms in the world of fashion: denim/jeans, clutch and print, three items included in all three glossaries evoked, Fundéu, EnFemenino and ComparteModa. As the above examples show, the lexicographical attitudes in favor of Anglicisms are present in almost all entries, but for comparison purposes we compare the Anglicisms which are directly and explicitly addressed.

38 For the first case, denim/jeans, a comparison of the three glossaries is highly illustrative. While prescriptivists simply recommend not using the word (with a certain 
degree of confusion, as there is no information on the varieties of Spanish as far as vaquero or mezclilla are concerned), the other glossaries not only justify the usage, but promote it instead of the traditional vaquero form:

Figure. 3. - Denim in different glossaries.

\begin{tabular}{|l|l|l|}
\hline denim & tejido vaquero, mezclilla & Fundéu (2019) \\
\hline Denim & $\begin{array}{l}\text { El término Denim se asocia a cualquier prenda de tejido vaquero, ya sea } \\
\text { un pantalón, una camisa o incluso un bolso. ¿Una curiosidad? La palabra } \\
\text { denim viene del francés "de Nîmes", ciudad donde se encontraba la } \\
\text { primera fábrica de este tipo de tejido. }\end{array}$ & EnFemenino (2018) \\
$\begin{array}{l}\text { [The term Denim is associated with any denim clothing, whether } \\
\text { trousers, shirts or even bags. An interesting note: the word } \\
\text { "denim" comes from French "de Nîmes", the city where the first } \\
\text { factory making this fabric was located.] }\end{array}$ & $\begin{array}{l}\text { ComparteModa (2016) } \\
\text { es la tela con la que se hace los vaqueros o los jeans parece que "vaquero" } \\
\text { solo se le llama en nuestro país y no en todas las regiones. } \\
\text { [is the fabric used to make "vaqueros" or jeans; it seems that } \\
\text { "vaquero" is only used in our country, and not even in all regions.] }\end{array}$ & \\
\hline & & \\
\hline
\end{tabular}

In domains such as these, normative authorities have fruitlessly tried to eliminate all such occurrences and replace them by vaqueros or tejanos (or more "creative" adaptations, such as the supposedly successful bluyins, recommended by the Academia which is rarely, if ever, used), such proposals being consistently flouted by influencers:

Este año también se siguen llevando los tops lenceros, pues sinceramente son un básico en mi armario, los tengo en diversos colores y me gustan porque con una blazer y unos jeans quedan geniales. ${ }^{8}$

[This year lingerie tops are still in, because indeed they are a must in my wardrobe: I've got them in different colors, and I like them because they look great with a blazer and a pair of jeans.]

The situation of denim, for the type of fabric, is quite similar, because for the Real Academia, the Spanish institution which prescribes correct language use, denim does not and should not "exist" in Spanish although influencers use it unsparingly:

Hoy os enseño unas fotos en uno de mis sitios prefes de Barcelona, Arco de Triunfo y con una de mis tendencias prefes también, Denim. Espero que os guste y mucho amor! $!^{9}$

[Today I'm showing you a few photos in one of my fav places in Barcelona, the Arco del Triunfo, and with one of my fav trends as well, denim. I hope you like it!]

Este año la tendencia denim apunta muy alto y para el verano no puede faltar en nuestro fondo de armario un vestido de tejido denim. ${ }^{10}$ 
[This year the denim trend looks promising, and this summer we really need a denim fabric dress in our wardrobes.]

41 The second example of a preferred Anglicism is clutch. While prescriptivists offer three alternative terms such as bolso de mano, bolso de fiesta or simply cartera in their attempts to avoid the unadapted borrowing, the other glossaries fully embrace it, explain its use and even provide a plural form, even if it does not correspond with the correct English one.

Figure 4. - Clutch in different glossaries.

\begin{tabular}{|l|l|l|}
\hline clutch & bolso de mano, bolso de fiesta, cartera & Fundéu (2019) \\
\hline Clutch & $\begin{array}{l}\text { Aunque lo parezca, el término clutch no es ninguna onomatopeya, sino la } \\
\text { palabra que se utiliza en moda para referirse a los bolsos y carteras de } \\
\text { mano. De tela, cuero, plástico o incluso metacrilato, jtodo vale cuando } \\
\text { hablamos de clutchs! }\end{array}$ & EnFemenino (2018) \\
$\begin{array}{l}\text { [Even if it does seem so, the term "clutch" is no onomatopoeia, but } \\
\text { the word used in fashion to refer to handbags and purses. Made of } \\
\text { fabric, leather, plastic or even methacrylate, everything is } \\
\text { acceptable when talking about "clutchs".] }\end{array}$ & $\begin{array}{l}\text { ComparteModa (2016) } \\
\text { incorpora elementos que hacen de el [sic] un bolso-joya. } \\
\text { Clutch } \\
\text { includes elements which turn it into a jewel-bag.] }\end{array}$ & \\
\hline
\end{tabular}

Erea Louro (2016), a blogger who defines herself as "a freelance fashion stylist and blogger based in Madrid", in her article entitled "CLUTCH BORDADO", confirms the trend when she writes:

Hoy os enseño un look de la semana pasada, una sobre camisa larga que es perfecta para el entretiempo y que me puse para ir trabajar con un total look negro por debajo, sombrero de ala ancha, $y$ un clutch bordado de Myla. ${ }^{11}$

[Today I'm showing you a look from last week, a long shirt, perfect for spring and autumn, which I wore to work with a completely black look underneath, a wide-brimmed hat and an embroidered clutch bag by Myla.]

The third example selected for our purposes, print, also shows a marked difference between the prescriptivist approach, which simply offers a replacement, and the descriptivist glossaries, which not only accept the Anglicisms, but provide examples and hints for usage. 
Figure 5. - Print in different glossaries.

\begin{tabular}{|l|l|l|}
\hline Print & Estampado & Fundéu (2019) \\
\hline Print & Estampado. Por ejemplo "animal print". & EnFemenino (2018) \\
\hline Print & $\begin{array}{l}\text { La palabra print es la traducción literal de estampado, y como su propio } \\
\text { nombre indica, se utiliza para referirse a todas las prendas estampadas, ya } \\
\text { sea con motivos florales (floral print), de piel de animales (animal print), de } \\
\text { estrellas (galaxy print)... }\end{array}$ & ComparteModa (2016) \\
$\begin{array}{l}\text { [The word "print" is the literal translation of "estampado", and as } \\
\text { the name itself describes it, it is used to refer to all printed } \\
\text { garments, whether with flower motifs (floral print), animal skin } \\
\text { (animal print), stars (galaxy print)...] }\end{array}$ & \\
\hline
\end{tabular}

Print is also the choice favoured by Instagrammers, such as Sandra Cortés as, for example, when she writes:

¿SI O NO? ¿A la tendencia cadenas? Versace se encargó de popularizar este estampado algo barroco y ahora está por todas partes. Quizás sea un print algo difícil de llevar pero sin duda que aporta un toque de estilo a los looks. ${ }^{12}$

[YES OR NO to the chains trend? Versace popularized this somewhat baroque print, and now it's all over the place. This print may be a bit difficult to wear, but gives a touch of style to your look.]

This is a choice also supported by brand manufacturers and designers, such as Cyzone, Blanca Cuesta or Mi Vestidor Azul, as seen in the following examples:

Porque cuando te enamoras de un print, lo quieres en toooodas sus formas. ${ }^{13}$

[Because, when you fall in love with a print, you want it in aaaaaaall its shapes.]

El \#Cuadrille es un \#Print que nunca pasa de moda! ${ }^{14}$

[\#Cuadrille is a \#print that is never out of fashion.]

Esta temporada los lunares son un atractivo increíble. Y lo cierto es que es un print que nunca pasa de moda, siempre gusta, siempre existen colores nuevos y nunca defrauda. Todo son ventajas. ${ }^{15}$

[This season polka dots are incredibly attractive. And indeed they are a print that will never be out of fashion, always liked, there are always new colours and will never let you down.]

A rapid look at examples of real usage on social media confirms that, with rare exceptions (such as, for example, an online prescriptivist, @lavecinarubia), glossaries by bloggers are the best indicators of real usage, largely due to the fact that they have, consciously or not, chosen to describe and not to prescribe. One of the major reasons prescriptivists fail to prevail is that they are not aspiring members of the professions and their attempts, therefore, not only go against the anglicizing tendency, but are felt to come "completely from the outside", i.e. do not show "insider" knowledge of the profession and are, therefore, not worthy of consideration. As evinced by the examples, 
entries in the "outlier" glossaries tend to be more complete and show more specialized knowledge (even including pictures), which are more persuasive since they place them ideologically closer to users.

\section{Conclusions}

Speaking from a diachronic perspective, there has always been a traditional divide within the field of specialized or professional communication: on the one hand, there was the specialized text, subject to specific rules, where experts communicated with each other using the codified language of a trade or profession, with no need for explanation. On the other hand, there was the vulgarised or "divulgative" text, where informed intermediaries (journalists, linguists, or even professionals with a "divulgative" penchant) strove to make the intricacies of a professional activity comprehensible for the general public. These two worlds were seen as separate, with the latter viewed as unable to have any influence upon the professional sphere. While this may still be case with certain professional languages such as those of the "regulated" professions, as we have just seen, there are other professions in which genres originally targeting the general public may have the power to influence the professional codes, and where the non-specialized go-between may be "accepted" into the professional sphere. In these areas, power must be perceived as a dynamic process between the two parties and not as a binary situation with those who have power and those who bow down to it, but as a series of concentric circles which, in certain circumstances, allow the periphery to approach the core.

This situation has repercussions for ESP practice and for specialized translation: it is critical, for training purposes, to create awareness of these "non-hierarchical" specialized and professional spaces, since the acquisition of these codes is much more problematic and complex due to the fact that they are determined purely by usage, and that the universe of "users" is a much wider and more fluctuating one.

It goes without saying that analyzing norm-setting in terms of power and citing nontraditional communities does not mean that users are completely free to make their own decisions, unconditioned by external forces. In the case of users in the language of fashion, the situation may be explained by the fact that the "force" at work is the immensely powerful influence of English, which cannot be counteracted by any organized resistance put up by prescriptivists seeking to stop the flow of foreign terms. As seen from this discussion, the influence of English in the Spanish language of fashion, and the borrowings it entails, are supported in a structured systematic way from the "outside" by aspiring members, that is, by bloggers and influencers who are users with non-hierarchical but increasing power and whose capacity to disseminate and establish Anglicisms as part of the specialized language and discourse of the industry packs a heavy clout. 


\section{BIBLIOGRAPHY}

BALTEIro Isabel (2011a), "Prescriptivism and Descriptivism in the Treatment of Anglicisms in a Series of Bilingual Spanish-English Dictionaries", International Journal of Lexicography, 24(3), 277305.

BALTEIRo Isabel (2011b), “A Few Notes on the Vocabulary of Textiles and Fashion”, I. Balteiro (ed.), New Approaches to English Lexicology and Lexicography, Newcastle: Cambridge Scholars Press, 65-81.

BALTEIRo Isabel (2011c), “A General Overview of Fashion Anglicisms in Spanish”, S. MaruendaBataller \& B. Clavel-Arroitia (eds), Multiple Voices in Academic and Professional Discourse: Current Issues in Specialised Language Research, Teaching and New Technologies, Newcastle: Cambridge Scholars Publishing, 404-17.

BALTEIRo Isabel \& CAMPos Miguel Ángel (2012), “False Anglicisms in the Language of Spanish Fashion and Beauty", Ibérica, 24, 233-60.

BELChER Diane D. (2006), "English for Specific Purposes: Teaching to Perceived Needs and Imagined Futures in Worlds of Work, Study, and Everyday Life", TESOL Quarterly, 40(1), 133-56. BIELENIA-GRAJEWSKA Magdalena (2009), "The Role of Metaphors in the Language of Investment Banking", Iberica, 17, 139-56.

CAMPos Miguel Ángel (2011), "False Anglicisms in Legal and Business English as a Lingua Franca (ELF): A Process of Back-borrowing”, I. Balteiro (ed.), New Approaches to English Lexicology and Lexicography, Newcastle: Cambridge Scholars Publishing, 83-96.

CAmPoy-Cubillo Mari Carmen, GeA-VAlor Maria Lluisa \& Belles-Fortuño Begoña (eds) (2010), Corpus-Based Approaches to English Language Teaching, London: Continuum.

CRUZ Toni (2018), España como excusa, Sevilla: Punto Rojo.

CRYSTAL David (2003), English as a Global Language (2nd edition), Cambridge: Cambridge University Press.

FLOWERDEW Lynne (2005), “An Integration of Corpus-Based and Genre-Based Approaches to Text Analysis in EAP/ESP: Countering Criticisms against Corpus-Based Methodologies”, English for Specific Purposes, 24(3), 321-32.

Freberg Karen, Graham Kristin, McGaughey Karen \& Freberg Laura A. (2011), "Who Are the Social Media Influencers? A Study of Public Perception of Personality”, Public Relations Review, 37, 90-2. GIDDENS Anthony (1984), The Constitutional Society. Outline of the Theory of Structuration, Cambridge: Polity Press.

GRADDOL David (2006), English Next, London: The British Council.

JUNG Kerstin (2010), "World Cup Football Live on Spanish and Argentine Television: The Spectacle of Language", E. Lavric, G. Pisek, A. Skinner \& W. Stadler, The Linguistics of Football, Berlin: Narr Verlag, 343-58.

Mateo José (2014), "Neonyms for a Crisis: Cognitive, Terminological and Socio-Pragmatic Aspects in the Translation of New Financial Terms into Spanish", Babel, 60(4), 405-24.

McGrath Mary Ann \& OTNES Cele (1995), “Unacquainted Influencers: When Strangers Interact in the Retail Setting", Journal of Business Research, 32(3), 261-72. 
ORTS María Ángeles \& BREEZE Ruth (2017), “Introduction”, M. Á. Orts, R. Breeze \& M. Gotti (eds), Power, Persuasion and Manipulation in Specialized Genres, Bern: Peter Lang, 9-26.

PAltridge Brian \& StARfield Sue (2011), “Research in English for Specific Purposes”, E. Hinkel (ed.), Handbook of Research in Second Language Teaching and Learning (vol. 2), New York: Routledge, $117-21$.

Polsby Nelson W. (1959), “Three Problems in the Analysis of Community Power”, American Sociological Review, 24(6), 796-803.

PRATT Chris (1997), “Anglicisms in the Academy Dictionary: “No pasarán”, Estudios Ingleses de la Universidad Complutense, 5, 279-95.

QUIRK Ronald J. (2005), "The Appendix Probi as a Compendium of Popular Latin: Description and Bibliography", Classical World, 98(4), 397-409.

RESCHE Catherine (2015), "Mapping Out Research Paths to Specialized Domains and Discourse: The Example of Business Cycles and Financial Crises", Journal of Teaching English for Specific and Academic Purposes, 3, 215-28.

THE Sunday Times (2019), “The Sunday Times' Influencer List”, 8 September 2019.

\section{Webliography}

ASA (Advertising Standards Authority) (2019), “How Many Followers Makes a Celebrity? Medicines and Influencer Marketing", <https://www.asa.org.uk/news/how-many-followersmakes-a-celebrity-medicines-and-influencer-marketing.html> (accessed 28 January 2020).

“¡Atención, 'bloggers' de moda! Las palabras que usáis también existen en español”, Heraldo de Aragón, 28 March 2018, <https://www.heraldo.es/noticias/aragon/2018/03/28/atencionbloggers-moda-las-palabras-que-usais-tambien-existen-espanol-1231192-300.html> (accessed 30 May 2019).

"Diccionario Fashionista" (2016), available on Comparte mi moda, <www.compartemimoda.es/ 2016/01/diccionario-fashionista.html> (accessed 30 May 2019).

Directive 2005/36/EC of the European Parliament and of the Council of 7 September 2005 on the recognition of professional qualifications. Available on <https://eur-lex.europa.eu/legalcontent/EN/TXT/?uri=CELEX\%3A32005L0036> (accessed 30 May 2019).

FUNDÉU (2019), Moda: extranjerismos con equivalente en español, <https://www.fundeu.es/ recomendacion/moda-extranjerismos-con-equivalente-en-espanol-1226/> (accessed 28 January 2020).

GoNZÁLEZ Cristina (2018), “Diccionario de moda: términos imprescindibles”, Enfememino, $<$ www.enfemenino.com/tendencias/diccionario-moda-s2462108.html> (accessed 30 May 2019).

HunT Elle (2020), “Royals for Rent: Will Harry and Meghan Become the World's Biggest Influencers?", The Guardian, 23 January 2020, <https://www.theguardian.com/uk-news/2020/jan/ 23/royals-for-rent-will-harry-and-meghan-become-the-worlds-biggest-influencers $>$ (accessed 28 January 2020).

LEMENS Chris \& ADAMS Kenneth A. (2015), "Fixing Your Contracts: What Training in Contract Drafting Can and Can't Do", Docket, 22 September 2015, <www.accdocket.com/articles/fixingyour-contracts.cfm> (accessed 7 April 2019). 
LOURO Erea (2016), "Clutch bordado", available on All that she wants (blog),

<www.allthatshewantsblog.com/2016/04/clutch-bordado.html> (accessed 7 April 2019).

MAHESVARI Sapna (2018), “Are You Ready for the Nanoinfluencer?”, The New York Times,

11 November 2018, <https://www.nytimes.com/2018/11/11/business/media/nanoinfluencers-

instagram-influencers.html> (accessed 28 January 2020).

MEDIAKIX, "What Are Nano-Influencers", <https://mediakix.com/blog/what-are-nano-

influencers/> (accessed 30 May 2019).

\section{NOTES}

1. See, for instance, <https://www.notarypublicstamps.com/forms/california notarial certificates.pdf>.

2. See Directive 2005/36/EC, 2005 on the recognition of professional qualifications.

3. Some sources wrongly attribute the expression to Andrés Montes, a journalist who popularized it during the 2006 World Cup (e.g. Jung, 2008)). However, though it is true that he popularized the expression, it has been documented much earlier. It was used by Angel Cappa in an interview in 1996 (reproduced in <https://revistalibero.com/blogs/contenidos/el-origen-del-tiki-taka>) and became the subject of mockery by coaches who opposed this system, like Javier Clemente (see Cruz, 2018: 88). What Montes did was change the connotations of the word, which Clemente identified with boring, unproductive play.

4. For a few examples, see <https://mediakix.com/blog/best-influencer-marketing-examples-toknow/>.

5. See <www.dulceida.com/2014/01/fashion-blogger-awards-stylight-im.html>.

6. <www.enfemenino.com/tendencias/diccionario-moda-s2462108.html>.

7. All translations from Spanish into English done by authors.

8. <https://mivestidoazul.com/fashion/atrevete-con-la-moda-lenceria/>.

9. $<$ www.dulceida.com/2012/12>.

10. <https://mivestidoazul.com/fashion/5-tipos-de-vestidos-para-triunfar-este-verano/>.

11. <www.allthatshewantsblog.com/2016/04/clutch-bordado.html>.

12. <www.instagram.com/p/BtL-41fnOU6/>.

13. $<$ www.instagram.com/p/Bxuz-gkAG-w/>.

14. <www.instagram.com/p/Bx0WrW2jfgD/>.

15. $<$ www.instagram.com/p/ByI02QXoTE5/>.

\section{ABSTRACTS}

The norm in languages for specific purposes, i.e. acceptability in terms of language use at all levels, from pronunciation and lexis to genre structure, is usually established in terms of the power over discourse exerted by user communities. However, in "non-hierarchical" or even "non-regulated" professions or areas of LSP, there is a gradation between lay and professional users which makes for boundaries that are moveable. "Influencers", who use social media (Instagram, Twitter, etc.) to disseminate their ideas about fashion, are a case in point: they rarely 
(if ever) have any academic qualifications in fashion design, but may progressively become empowered, through their influence on social media, to determine language use in the language of fashion. The consequences of this empowerment of "outliers" would affect, amongst other components, the normativization of certain specialized languages: as influencers progressively approach the core of the profession, they may bring with them a host of borrowings-mainly Anglicisms in the case of Spanish influencers-which they then disseminate, in spite of what purists might argue. In our paper, we shall use the language of fashion as a case in point to show that the establishment of a norm is not necessarily subject to traditional hierarchies, and discuss the creation of (em)power(ment) dynamics which lead to visible results in language practices.

La norme en langues de spécialité - c'est-à-dire l'acceptabilité en termes d'usage à tous les niveaux, de la prononciation et le lexique à la structure des genres - relève habituellement du pouvoir qu'exerce la communauté d'utilisateurs sur le discours. Cependant, dans le cas des professions ou domaines de spécialité "non hiérarchisés" ou "non régulés ", il existe une graduation entre l'utilisateur professionnel et l'utilisateur amateur qui crée des frontières mobiles, voire dichotomiques. Les « influenceurs » qui se servent des réseaux sociaux (Instagram, Twitter, etc.) pour diffuser leurs idées sur la mode en sont un exemple : ils possèdent rarement des diplômes en stylisme mais peuvent, à travers leur influence dans les réseaux sociaux, être investis du pouvoir d'influer sur la langue de la mode. Une telle habilitation de ces acteurs en marge de la profession agit sur la normalisation de certaines langues de spécialité : au fur et à mesure qu'ils se rapprochent du cœur de la profession, ils amènent dans leur sillage de nombreux emprunts - essentiellement des anglicismes dans le cas des influenceurs espagnols qui se perpétuent quoi qu'en puissent dire les puristes. Cet article prend l'exemple de la langue de spécialité de la mode comme un cas d'espèce: en mettant en lumière comment la reconnaissance des acteurs périphériques peut conduire à des résultats visibles dans la pratique de la langue, il démontre que l'établissement d'une norme n'est pas nécessairement soumis à des hiérarchies traditionnelles.

\section{INDEX}

Mots-clés: anglicismes, influenceurs, établissement des normes, langues de spécialité Keywords: Anglicisms, influencers, norm-setting, languages for specialized purposes

\section{AUTHORS}

\section{MIGUEL ÁNGEL CAMPOS-PARDILLOS}

University of Alicante.

Miguel Ángel Campos-Pardillos is a Lecturer in Legal English and Translation at the University of Alicante (Spain), and has published books and papers on specialized lexicology and lexicography, including dictionaries (Human Rights and Real Estate Language, amongst others). He has authored a number of contributions on Anglicisms in Western European languages.

ma.campos@ua.es

\section{ISABEL BALTEIRO}

University of Alicante.

Isabel Balteiro is a Lecturer in English at the University of Alicante (Spain). She has published two monographs on English word formation in Peter Lang and Waxmann, and has written a number of articles and book chapters on English Lexicology and Word-Formation. She has published 
extensively on the lexis of fashion, Anglicisms and code-switching in specialized languages.

balteiro@ua.es 